\title{
Texter och offentlig makt - språk och språkvetenskap i samhället
}

\author{
Ulla Tiililä
}

\section{Inledning}

Ämnet språk och rätt kan behandlas ur många olika perspektiv. Det viktigaste perspektivet är troligtvis språkets inverkan och roll dels vid tillgodoseendet av människors rättigheter, till exempel beslutsfattande i första instans, dels vid rättsskipning, till exempel $\mathrm{i}$ domstolarnas och polisens arbete (Gunnarsson 2009:99-141; Johnson \& Coulthard 2010; Tiililä 2018a: 381-405). Då granskas vanligtvis särdragen hos det språk som har använts, och det görs kanske även en bedömning av hur lyckade de språkliga valen har varit i sin kontext.

I utvecklingen av den offentliga makten och förvaltningen har språket och texterna lyfts fram inom myndighetsspråkvården. Då har man i huvudsak fäst uppmärksamhet vid myndigheternas verksamhet och det språk de använder och texternas kvalitet, som man har ansett vara av central betydelse för att demokratin ska förverkligas (se Myndigheternas skrivregler). I bakgrunden finns också de lagar genom vilka myndigheternas språkbruk regleras. I Finland kräver t.ex. förvaltningslagen (9 §) god språkanvändning av myndigheterna.

Men vad händer när man i diskussionen om språk och rätt riktar blicken från språket mot språkliga betydelsehelheter, det vill säga mot texter, och från språkliga produkter mot språkliga processer, alltså t.ex. mot skrivande? I den här artikeln behandlar jag textdominansen inom den offentliga makten, förvaltningen och servicen - och i synnerhet inom social- och hälsovårdsväsendet - och texternas förhållande till tillgodoseendet av de sociala rättigheterna. Jag försöker visa att deras förhållande också påverkar andra typer av rättsvärldar, i slutändan till och med det kriminalpolitiska området. Med offentlig makt avser jag framför allt statens och kommunernas samt de underlydande ämbetsverkens och serviceorganisationernas verksamhet och regleringen av deras verksamhet genom lag (se Mäenpää 2013:138-140).

Språk, skrivande och texter har en stor och övergripande samhällelig betydelse. Därför försöker jag också visa att det inom språk- och textforskningen finns ramar som kan vara viktiga att tillämpa i större utsträckning än vad som nu görs för att utveckla förvaltningen och den offentliga servicen.

Min breda referensram är skrivandets sociolingvistik (Lillis 2013; Lillis \& McKinney 2013, se även t.ex. Blommaert 2012), som dock har många beröringspunkter med diskurs- och genreforskning. Dessa forskningsgrenar fokuserar inte enbart på texter, dvs. lingvistisk output eller lingvistiska produkter, 
utan även på social praxis och processerna vid språkanvändning och produktion, tolkning och konsumtion av texter (Fairclough 1992:71-73; se även t.ex. Brown \& Yule 1983; Tiililä 2007).

Dessa traditioner inom språk- och textforskningen har också samband med myndighetsspråkvården och utvecklandet av myndighetsspråket. Till exempel inom myndighetsspråkvården i Finland har man länge ansett att om det finns problem i texter är det mer ändamålsenligt att ta itu med orsakerna till dem än att gång på gång ingripa endast i konsekvenserna (Tiililä 2007:16; se även Heikkilä \& Viertiö 2002:247-248; Tiililä 2001:11). Därför har man undersökt och utrett inte bara egenskaperna hos myndighetsspråket och myndighetstexterna utan också deras uppkomstmekanismer och andra bakgrundsfaktorer. Till exempel Vijay Bhatia (1993:13-36; se även Swales 1990:6873) har redan tidigare talat för en omfattande och mångsidig granskning av texters bakgrund.

Enligt Theresa Lillis och Carolyn McKinney (2013: 417) är skrivandet ett socialt fenomen som tränger igenom allt. De (a.a.) betonar att skrivande är ett språkligt och kommunikationsrelaterat fenomen som kommer till uttryck i många former och material och genom många olika typer av teknologi.

Textdominansen och skrivandet löper naturligtvis parallellt, eftersom varje text kommer till i en process. Vid sidan av skrivande kan man tala om textarbete men också om produktion av text, eftersom det i det nuvarande arbetslivet och i synnerhet i förvaltningen uppkommer många texter som snarare produceras än skrivs. Till exempel förmånsbeslut, såsom beslut om utkomststöd, fattas halvautomatiskt $i$ en massproduktion, varvid man utnyttjar de textavsnitt, s.k. fraser, som finns färdigt inmatade i informationssystemet (Qvist 2017:112-114).

Av de ämnen och frågor som lyfts fram inom skrivandets sociolingvistik är i denna artikel särskilt relevant det faktum att skrivandet är osynligt, att det inte identifieras som verksamhet. Enligt Lillis (2013:76) är skrivandet så vardagligt och vanligt att det kan bli omärkbart. Man har också ansett att orsaken till osynligheten (Tiililä 2017:63-68) är bristfällig språkmedvetenhet: å ena sidan identifieras inte den informationsbehandling, dokumentation eller registrering som ingår i arbetet som verksamhet där man gör språkliga och textuella val. $\AA$ andra sidan ses språkbruket inte som en social och materiell process där texternas språkliga drag är en följd av arbetspraxis eller exempelvis av möjligheterna och begränsningarna i de tekniska skrivmedlen, såsom informationssystemen. Blommaert (2012:7-8) talar om skrivandets infrastruktur. Till detta hänför sig en annan central bakgrundstanke i artikeln, nämligen Lillis (2013:17) fråga om vilken funktion skrivandet har och hur denna funktionen har identifierats. Mitt antagande är att skrivandet ofta betraktas som en individuell kreativ process och att dess samband med den sociala praxisen eller de tekniska lösningarna inte identifieras. Jag undersöker också konsekvenserna av denna felaktiga identifiering. Jag är särskilt intresserad av den materiella effekten av skrivandet. Skrivandet är mångfasetterat 
och multidisciplinärt i arbetsgemenskapen och sker med hjälp av tekniska lösningar. Det tar och kräver alltså resurser och kompetens och styr verksamheten. Det har samhällelig och politisk betydelse om detta inte identifieras.

Jag disponerar min artikel så, att jag först med hjälp av ett exempel visar vad textdominans är i praktiken. Eftersom artikeln fokus ligger på språket, och den offentliga makten har jag valt till exempel den finska regeringens (2015-2019) reform av social- och hälsovården och de lagutkast som ingår i den. Jag granskar dessa genom att lyfta fram det textarbete som ingick i reformen: det textarbete som ingår i lagutkasten och den ställning textarbetet har. Efter att jag med hjälp av exemplet har presenterat textdominansen, fortsätter jag på den av Bhatia (1993:13-36) utstakade vägen för att diskutera vad textualiseringen beror på - kan det handla om en megatrend? Textualiseringen är till exempel en följd av olika filosofier kring arbetsledning, men vad har textualiseringen för konsekvenser för arbetet och arbetstagarna, framför allt inom det människocentrerade social- och hälsovårdsarbetet? Textdominansens konsekvenser för arbetet behandlar jag genom forskningslitteraturen. Huvudsakligen på samma sätt granskar jag också de olika konsekvenser som textualiseringen har för medborgarna och brukarna av offentliga social- och hälsovårdstjänster. Jag återkommer här genom exempel också till social- och hälsovårdsreformen ur medborgarnas synvinkel.

Min frågeställning utgår från skrivandets sociolingvistik, men allt eftersom artikeln framskrider kommer det att synas spår av genreforskning, liksom ur ett fågelperspektiv: jag börjar med det statiska, dvs. texten (exemplet med lagreformen) och går vidare till processer samt textproduktion och textkonsumtion.

Eftersom en bakgrundstanke till artikeln är att skrivandet är osynligt, är min artikel i huvudsak av översiktstyp: jag granskar tidigare undersökningar och andra publikationer och lyfter fram iakttagelser om texter, textarbete och skrivande. Jag anser nämligen att man åtminstone i Finland inte i tillräcklig utsträckning har identifierat den kommunikativa eller textuella karaktären för många samhälleliga problem, trots att de redan i årtionden har blivit framlagda för oss i undersökningar och utredningar. Däremot konstaterar finska lingvister Riikka Nissi och Suvi Honkanen (2015:2) att lingvister själva inte har tillräckligt uppmärksammat informationsarbetets språkliga karaktär. Lotta Wendel (2019:14) som har forskat i dokumentering inom social- och hälsovården ur ett juridiskt perspektiv konstaterar i sin tur att "Det har knappast undersökts tidigare hur dokumentationsskyldigheten växt fram på hälso- och sjukvårdsområdet och hur regleringens utformning och tillämpning inverkar på professionernas yrkesutövning”. 


\section{Textualiseringsbild: Den finländska social- och hälovårdsreformen}

Olli Mäenpää (2000:151), som är professor emeritus i förvaltningsrätt vid Helsingfors universitet har konstaterat att "den yttre formen av den användning av offentlig makt som ingår i en förvaltningsakt är vanligtvis ett skriftligt förvaltningsbeslut, som inkluderar ett avgörande i ett förvaltningsärende" (översättning: Semantix Finland).

Vid sidan av besluten utarbetas naturligtvis även hundratals andra texter inom tjänstesektorn, till exempel planer, anvisningar, program och rapporter. FPA, den finländska Folkpensionsanstalten, fattar till exempel årligen cirka 19 miljoner beslut om olika förmåner, och Finlands befolkning är alltså 5,5 miljoner människor. Det kan konstateras att den offentliga makten i stor utsträckning konkretiseras just med hjälp av texter och språk (Tiililä 2015:100).

Den offentliga makten byggs upp och formuleras som lagar som i sig är texter; också lagberedningsprocessen domineras av olika texter (se t.ex. Processhandbok). Verkställandet av lagarna sker med texter, såsom just beslut, avtal, planer eller t.ex. pressmeddelanden och utredningar. Till det mångfasetterade förhållandet mellan den offentliga makten och texterna hör alltså också att en stor del av de texter som kommer till inom myndigheter och offentliga tjänster i sig är lagstadgade.

För att belysa detta ska jag göra en exkursion till den vårdreform som Finlands regering (2015-2019) beredde och som var förknippad med en landskapsreform. Bakgrunden till reformen var, att mindre kommuner hade svårigheter att klara av sina lagstadgade uppgifter. Enligt Sonja Manssila och Lotta Mattsson (2019:11) hade flera regeringar "försökt åtgärda problemet genom att förplikta kommuner att samverka eller gå samman. Differentieringen mellan kommunerna, den åldrande befolkningen, ökningen av socialoch hälsovårdskostnaderna och urbaniseringen bidrog till att öka trycket på strukturreformer". Vidare ansåg de att "[m]ålet med landskaps- och vårdreformen som inleddes 2015 var att erbjuda människor mer jämlika tjänster, minska hälso- och välfärdsskillnaderna och dämpa kostnadsökningen". Reformen sprack våren 2019 och fällde till sist hela regeringen (Manssila \& Mattson 2019:23, 35, 87).

Det finns dock fortfarande mycket intressant att granska i reformplanerna, i synnerhet eftersom Sanna Marins regering, som utsågs 2019, för sin del försöker reformera social- och hälsovården delvis med samma eller nästan samma lagutkast. Jag börjar med några anteckningar om ordval, nominering och kategorisering.

Pauli Rautiainen, Helena Taskinen och Sari Rissanen (2020:38) har granskat reformprocessen ur juridiskt och samhällsvetenskapligt perspektiv. De lyfter till exempel fram hur man i olika sammanhang talade om den avslagna reformen som en förnyelse, reform, förändring eller utveckling av 
social- och hälsovården (a.a.:39) och hur alla dessa har en något annorlunda innebörd. Genom orden skapades föreställningar också i övrigt.

Ett centralt mål för reformen var att öka människors valfrihet för socialoch hälsovårdstjänster, och i det syftet framlades ett lagförslag om kundens valfrihet inom social- och hälsovården (RP 16/2018 rd, 367). Även här rörde man sig kring starka föreställningar som skapats med språket. Talet om valfrihet och kundens rätt att välja (4 §, a.a.:369) aktualiserade betydelser som alltid har varit synnerligen laddade i mänsklighetens historia: det har krigats och dödats för frihet. Frihet eller rätt att välja skapar en tolkningsram där människan har möjlighet att fatta individuella beslut i sitt liv utifrån sina egna behov och intressen. I lagutkastet rörde man sig alltså i en värld med stora betydelser.

När det i $4 \S$ i valfrihetslagen talades om kundens rätt att välja, övergick man i följande paragraf, 5, till en helt annan värld. Där stadgades det nämligen om en text, en kundplan. ${ }^{1}$ Familje- och omsorgsministern i regeringen 2015-2019, Annika Saarikko, karakteriserade planens betydelse i reformen så här:

Och i kärnan av allt detta finns en särskild paragraf gällande kundplaner i valfrihetslagen, alltså att man är förpliktad att göra upp en övergripande plan som alla delar av servicekedjan måste följa [-- ] (Saarikko 2017, översättning: Semantix Finland).

En text som man hade enorma förväntningar på höll på att bli kärnan i valfriheten. Planen skulle omfatta klientens alla social- och hälsovårdstjänster oavsett produktionsansvar. Det här innefattar många slags problem. Multidisciplinärt samarbete som är kopplat till dokument kan vara svårt redan inom en organisation (Wendel 2019:22-24). Hur skulle ett kanske oförutsett samarbete mellan flera aktörer, där skötseln av samarbetet hänger på ett dokument, se ut i praktiken? Det skulle ha varit ett stort och svårfångat sakkomplex för en text. Planer inom social- och hälsovården struktureras och standardiseras ofta för att effektivisera det multidisciplinära samarbetet och informationsutbytet. Wendel (2019) har dock observerat att användning av standardiserade vårdplaner kan hota patienternas rättssäkerhet. Wendel (2019, t.ex. 56) upptäckte i sitt undersökningsmaterial att

[m]ajoriteten av de standardiserade vårdplanerna var inte konstruerade för samråd med patienten och inte heller konstruerade så att patientens rätt till

\footnotetext{
1 Den svenska läsaren bör notera att det i finskan endast finns en motsvarighet till de svenska orden klient och kund, dvs. asiakas (se Gustafsson 2014), och den livligaste diskussionen har förts främst om huruvida ordet potilas (patient) eller asiakas ska användas inom hälso- och sjukvården (t.ex. Karppinen 2019). I detta sammanhang förblir det oklart hur medvetet valet av kundplan i den svenskspråkiga lagen har varit. I övrigt används i det svenska myndighets- och författningsspråket i Finland dock termen klientplan. I Finland finns t.ex. lag om klienthandlingar av socialvården, där det föreskrivs om klientplaner (16 §).
} 
information kunde antas vara tillgodosedd. Detta innebar att vårdplaneringen riskerade att framstå som obegriplig och otillgänglig för patienten [-- - ].

(Wendel 2019:56)

Standardisering behövs av många orsaker (Wendel 2019:24), men samtidigt är varken standardiseringen eller det multidisciplinära samarbete som är kopplat till den fria från problem.

En av de knivigaste frågorna i reformen var om planen blir juridiskt bindande eller inte. Således höll det på att ske en betydande förändring i plangenren: till skillnad från beslut är planer i allmänhet nämligen inte juridiskt bindande. Skillnaden mellan genrerna har utkristalliserats i deras namn (se t.ex. Swales 1990:54-57). Ett liknande problem löstes med det servicelöfte som planerades för reformen. Enligt Rautiainen et al. (2020:30) kan ett servicelöfte dock inte ges i juridiskt bindande form, utan det är snarare fråga om att uttrycka en vilja. Den bedömning och övervakning som ingick i reformen var dock avsedd att gälla just genomförandet av dessa löften (a.a.:36).

Låt oss titta på ännu ett annat lagförslag som anknyter till reformen, nämligen lagförslaget om ordnande av social- och hälsovård (RP 15/2017 rd). Det sades att syftet med den här lagen var "att främja och upprätthålla befolkningens välfärd och hälsa samt säkerställa jämlika social- och hälsovårdstjänster med god produktivitet $\mathrm{i}$ hela landet" $(1 \S)$. Men hur främjas befolkningens välfärd och hälsa? Jag gick igenom lagförslaget och hittade över 40 namngivna texter, till exempel dessa:

rapport, initiativ, förordning, utredning, förslag, välfärdsberättelse, regional välfärdsberättelse, ett samarbetsavtal för varje samarbetsområde, landskapens samarbetsavtal, servicestrategi, landskapsstrategi, landskapets servicelöfte, samarbetsområdets investeringsplan, statsrådets beslut, landskapens program för egenkontroll, tjänsteproducenternas program för egenkontroll, plan för främjande av kvalitetsledning samt klient- och patientsäkerhet, kundplan, ett dokument om de förda förhandlingarna.

Dessutom innehöll lagförslaget substantiv som i praktiken syftar på texter. Till exempel är uppgift, data och information ganska ofta i verbal form. Observationer eller erfarenhet måste i allmänhet också omvandlas till verbal form, texter, om man vill förmedla dem från en person till en annan. Vidare innehöll lagförslaget rikligt med verbalsubstantiv som i det dagliga arbetet innebär arbete med texter och dokument. Exempel på sådana är planering, bedömning, styrning och tillsyn. Även om lagförslaget sades gälla ordnandet av social- och hälsovården behandlade det $\mathrm{i}$ praktiken vem som borde ha utarbetat vilka texter, tillsammans med vem och hur ofta.

I 27 § i lagförslaget stadgades det om hur man borde ha berett de nationella målsättningarna. Man hade noggrant tänkt ut genom vilka slags processer beredningen av målsättningarna skulle ha framskridit. Dessutom borde man 
ha följt genomförandet av dem: även uppföljning och utvärdering är naturligtvis textuella processer. I texten nedan framhäver jag de olika texterna som nämns med fet stil, medan jag har strukit under verb och andra ord som i praktiken betyder textarbete:

\section{$27 \S$}

Beredning av de riksomfattande målen

Social- och hälsovårdsministeriet bereder förslaget till riksomfattande mål enligt

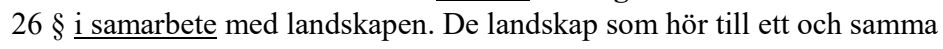
samarbetsområde ska utarbeta och lämna social- och hälsovårdsministeriet ett gemensamt förslag till hur tjänsterna i området och utvecklandet av dem samt samarbetet mellan landskapen borde beaktas i de riksomfattande målen.

Landskapen ska beakta uppföljningsuppgifterna om befolkningens välfärd och hälsa samt befolkningens servicebehov.

Samarbetsområdets förslag ska godkännas av landskapsfullmäktige i alla landskap i området.

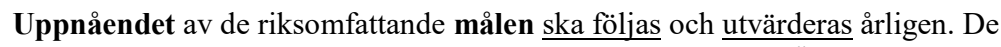
strategiska mål som statsrådet fastställt ska ändras vid behov. Ändringen kan basera sig på ett eller flera landskaps begäran eller social- och hälsovårdsministeriets initiativ.

Den styrning och rådgivning inom social- och hälsovården som hänförde sig till reformen såg i diagramform enligt Nykänen et al. (2017:48) ut så här:

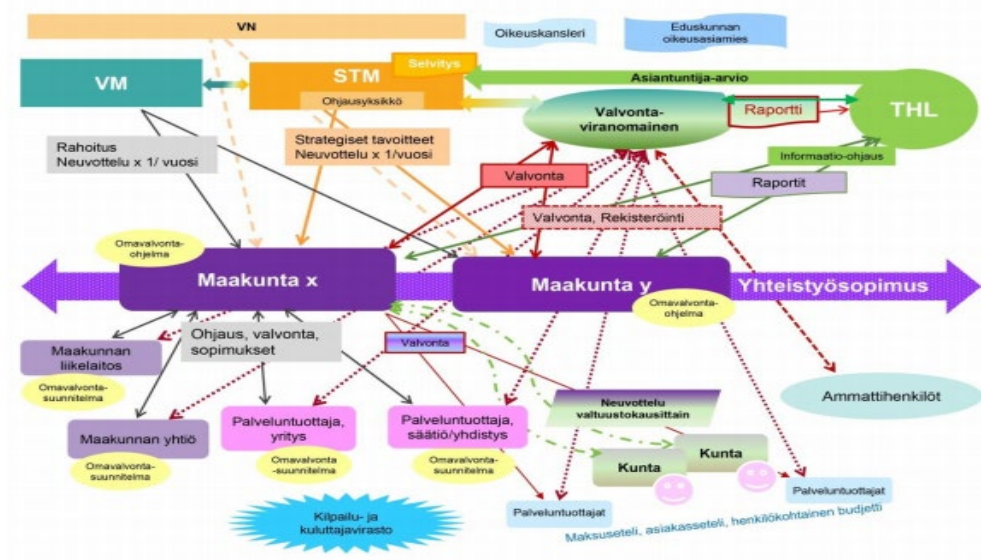

Kuvio 1. Sosiaali- ja terveydenhuollon ohjaus ja valvonta uudessa rakenteessa

Bild 1. Styrning och tillsyn av social- och hälsovården i den nya strukturen enligt Nykänen et al. (2017:48). 
Uppmärksamheten fästs naturligtvis vid strukturen, som verkar komplicerad och rörig. En textforskare lägger dock märke till att också det här diagrammet endast visar vem som ska utarbeta vilka texter och när. I de gula ovalerna nämns till exempel program och planer för egenkontroll (omavalvontaohjelma, omavalvontasuunnitelma). Under landskapen (maakunta), som har märkts ut med lila, omnämns styrning, tillsyn och avtal (ohjaus, valvonta, sopimukset), och vid den lila pilen omnämns samarbetsavtal (yhteistyösopimus). Mellan de gröna ovalerna omnämns i sin tur rapporter (raportti) och vid pilen expertbedömningar (asiantuntija-arvio) och så vidare.

Ändå nämndes det ingenstans att det är fråga om just texter, språkliga helheter. Det fanns heller ingen bedömning av vilka slags resurser textarbetena skulle ha krävt: hur mycket resurser de skulle ha krävt och vilken slags kompetens det skulle ha behövts för att utarbeta dem. Det talades visserligen om kommunikation i samband med reformen, men närmast om hur experter som sköter kommunikationen borde kommunicera innehållet i reformen. Det saknades insikt om att reformen på många sätt handlade om just text- och språkarbete.

Textarbetet bör identifieras som en del av bedömningen av författningarnas konsekvenser, där den så kallade administrativa bördan bedöms. Med det avses t.ex. lagstadgad anmälnings- och rapporteringsskyldighet för företag (Keinänen \& Pajuoja 2020:26). Det verkar dock som om bedömningen inte omfattar det multidisciplinära samarbete (se t.ex. Tiililä 2000:221) som behövs för att utforma och genomföra nya texter och modelltexter. Keinänen och Pajuoja (2020:68), som utrett behoven att utveckla bedömningen av författningars konsekvenser, konstaterar att en förbättring av effektiviteten och en minskning av den administrativa bördan kan i regeringspropositionerna användas som ett retoriskt argument utan att några konkreta konsekvenser presenteras. Enligt dem (a.a.) har det i extrema fall verkat som om man inte ens vetat vad till exempel den administrativa bördan innebär.

\section{Vad är orsaken till textualiseringen? Textualisering som megatrend}

Vad beror textdominansen eller textualiseringen på? Jag anser att det i bakgrunden finns ett fenomen i som kan jämföras med en megatrend (se Tiililä 2017:15). Med en megatrend avses stora utvecklingsvågor eller utvecklingslinjer och utvecklingshelheter som inkluderar olika fenomen som ofta leder i samma riktning. Begreppet används vanligtvis inom framtidsforskning (Mannermaa, 2004:43-44). Nu talar jag dock om ett fenomen som har varit rådande ganska länge redan (se t.ex. Iedema \& Scheeres 2003; Karlsson 2006:10-11).

Till följd av textualiseringen uträttas till exempel ärenden hos myndigheter och företag allt oftare skriftligen och den muntliga kommunikationen minskar: kontor läggs ner, uträttandet av ärenden via serviceluckor inskränks och telefonnumren försvinner från kontaktuppgifterna. 
Givetvis kan även andra och motsatta trender leva samtidigt och parallellt med varandra, till exempel nya muntliga kommunikationskanaler som poddsändningar eller serier som sprids till officiell kommunikation. Gemensamt med förskriftligandet är att kommunikationen är medierad i båda trenderna.

När antalet texter ökar uppkommer det även nya genrer, till exempel servicelöften. Men det uppstår även nya undertyper av genrer, till exempel olika nya planer, så som investeringsplan, plan för kvalitetskontroll och kundoch patientsäkerhet, plan för egenkontroll, plan för att stödja den äldre befolkningen.

Utarbetandet av texterna är lagstadgat (se t.ex. Tiililä 2018b) och olika incitament är kopplade till upprättandet av dem, medan olika påföljder är att vänta om texterna inte skrivs. I Finland bestäms t.ex. utarbetandet av en räddningsplan av räddningslagen och räddningsförordningen, och för underlåtenhet att upprätta en räddningsplan kan böter dömas ut. Sjukförsäkringslagen $(1224 / 2004 ; 5$ §) uppmuntrar arbetsplatserna att i samarbete med företagshälsovården komma överens om praxis för "hur hanteringen, uppföljningen och det tidiga stödet av arbetsförmågan ska genomföras som en gemensam verksamhet för arbetsplatsen och företagshälsovården”. Detta har lett till texter som kallas modeller för tidigt ingripande, omsorg eller stöd. Utarbetandet av texter för tidigt ingripande har ekonomiska konsekvenser. Dessa texter betraktas nämligen som förebyggande företagshälsovård. Enligt sjukförsäkringslagen är det möjligt för en organisation att få en ersättning på 60 procent för den förebyggande företagshälsovården endast om modellen för tidigt stöd används, dvs. om organisationen har en sådan text skriven.

Textualiseringen kan anses vara en del av megatrenden digitalisering, men den skulle kunna vara en megatrend också i sig själv. Många faktorer leder nämligen till samma slutresultat: Digitaliseringen och den övriga tekniska utvecklingen ökar textualiseringen.

Det finns dock även andra fenomen som leder till textualisering. I Finland har den under decenniernas lopp ökat till följd av att man inom den offentliga förvaltningen har övergått från normstyrning till informationsstyrning (se Riksdagen 2008). Redskapen är bl.a. statistik och forskningsinformation, register- och utvärderingsinformation, utvecklingsprojekt, handböcker, (kvalitets)rekommendationer och program.

Alla dessa är texter. Kvalitetsledning, managerialism (New Public Management) och resultatmätning inom den offentliga förvaltningen har också lett till textarbete. När tjänster inom den offentliga förvaltningen externaliseras når samma utveckling även den privata sidan, där företagen förutsätts producera olika dokument till exempel för kontroll av deras verksamhet.

Det finns alltså flera motiv till dokumenteringen (se Tiililä 2011:169-170), och den är även fast knuten till uppkomsten och utvecklingen av tekniska system och applikationer. Sirpa Saario (2011:182), som har forskat i mentalvårdsarbete, har konstaterat att ett centralt motiv till teknologiseringen av mentalvårdsarbetet är att göra arbetet utvärderingsbart. Samma 
problematiska följd av managerialismen framförs av Wendel (2019:67/155). Enligt henne har "målsättningen att skapa en effektiv och utvärderingsadministration en avgörande inverkan på dokumentationen av vården, inte minst $\mathrm{i}$ form av vårdplanering" (a.a.).

\section{Textualiseringens betydelse: Arbete med människor blir arbete med texter}

Den ökande textmängden har en ofrånkomlig inverkan på arbetet. Särskilt stor inverkan har den inom arbete med människor, där kärnan i arbetet typiskt sett har varit att möta människor ansikte mot ansikte och ofta även röra vid dem, vårda dem och sköta dem (se t.ex. Karlsson 2006:65-73; Wendel 2019:19-20). I det här arbetet skulle arbetstagarna på basis av sin yrkesetik ofta föredra kommunikation ansikte mot ansikte framför skriftlig kommunikation (t. ex. Stensöta 2010:298, 300).

Dokumenteringen inom arbete med människor beror delvis på redovisningsskyldigheten. Kirsi Juhila (2009:297), professor i socialt arbete, påminner om att redovisningsskyldigheten inte bara gäller yrkesmänniskor inom socialt arbete, utan även andra yrkesutbildade personer som arbetar med människor, till exempel lärare, psykologer, läkare, poliser och jurister. Sarah Banks (2004: 150), professor i tillämpad samhällsvetenskap, för fram att yrkespersoner inom branscher av det här slaget är redovisningsskyldiga gentemot användarna av deras tjänster. Eftersom man inom dessa branscher ofta sköter offentliga uppgifter finns det även ett mer allmänt samhälleligt intresse av att följa upp verksamheten (Banks a.a.). Denna uppföljning påverkar dock arbetet.

I Finland lägger upp till en fjärdedel av daghemspersonalen arbetstid motsvarande en arbetsdag per vecka eller mer på noteringar och skrivande. Resultat av det här slaget framkom år 2009, när Institutet för de inhemska språken lät genomföra en nationell enkät om skrivande i daghemmen. Svarspersonerna fanns runt om i Finland och var totalt cirka 1300 till antalet (Pyhäniemi 2017).

Teppo Kröger (et al. 2018), professor i samhällspolitik, har tillsammans med sina kollegor publicerat färskare resultat i en komparativ nordisk undersökning om äldreomsorg. Enligt Kröger et. al (2018:16):

[d]en största förändringen på tio år har varit att de administrativa uppgifterna och skrivandet har ökat. Andelen arbetstagare som dagligen skriver eller utför andra administrativa uppgifter har ökat med över 40 procentenheter, eftersom i praktiken alla (97 procent) dagligen utför uppgifter av det här slaget 2015. (Kröger et al. 2018:16, översättning: Semantix Finland)

Denna förändring var gemensam för både hemvården och institutionsvården. Samtidigt rapporteras det att personalen har allt mindre tid för kunder och patienter: 
En annan betydande förändring är att personalen allt mer sällan kan lägga tid på att ge kunderna socialt stöd och social interaktion. Andelen arbetstagare som har dagliga gemensamma kaffestunder med sina klienter har rasat på tio år (25 procent $\rightarrow 5$ procent). (Kröger et al. 2018: 18, översättning: Semantix Finland)

Det går att se en koppling mellan utvecklingstendenserna. När man lägger till något $\mathrm{i}$ arbetet, måste man oundvikligen minska på någonting annat. I Krögers et al. (2018:17) undersökning ansåg 72 procent av respondenterna att registreringen tar för lång tid. Ett liknande budskap har framförts i många andra publikationer. Wendel (2019:18-21) redogör för situationen inom den svenska hälso- och sjukvården och citerar även undersökningar om t.ex. den amerikanska och den danska hälso- och sjukvården. Även i Finland har problemet framkommit t.ex. vid en undersökning av hur belastande arbetet och användningen av teknik är för anställda inom äldreomsorgen: Arja Rytkönen (2018:168) har kommit fram till att nästan tre fjärdedelar av vårdgivarna anser att det går för mycket arbetstiden till att registrera olika saker på dator. Många upplevde också att man med hjälp av tekniken försöker ersätta för mycket växelverkan mellan människor inom omsorgsarbetet (Rytkönen a.a.). Enligt en undersökning utförd av Vehko (et al. 2015:21) upplever största delen (94 \%) av läkarna vid hälsostationerna att det finns för många olika utlåtanden, att de måste utarbetas för många olika instanser $(88$ $\%)$ och att de tar för mycket arbetstid (88 \%). Utlåtandena är i allmänhet lagstadgade och man måste hitta tid för dem $\mathrm{i}$ arbetet: det kan till och med hända att socialombudsmannen blir tvungen att påpeka detta i sin årsrapport (Loippo 2019:7). Vidare framgår det också t.ex. av enkäterna till sjukskötarna att registreringen upplevs ha ökat och att det sägs ta för mycket tid från patientarbetet (t.ex. Haapamäki \& Hyry 2015:31; Peippo \& Turunen 2015:21).

Textualiseringen av arbetet inverkar alltså ofrånkomligen på vart resurserna allokeras i arbetet. Den påverkar även kvaliteten på klient- och patientarbetet. Typiskt är dock att man i till exempel debatten om äldreomsorgen närmast talar om antalet vårdare: arbetets textdominans negligeras. I Finland talar man inte om den i medierna och söker inte politiska lösningar på den. Inte ens Kröger och hans kollegor verkar ha lyft fram detta centrala resultat på något sätt.

Låt oss slutligen ta ett exempel från äldreomsorgen. I Finland genomgick äldreomsorgen en kris 2019. I flera privata vårdhem avslöjades så allvarliga brister att vårdhemmen stängdes och verksamheten avbröts. Man hoppades få hjälp i situationen av den nya äldreomsorgslagen (565/2020), där det föreskrevs om minimiantalet vårdpersonal.

I den nya lagen avses med "direkt klientarbete" även registrering av klientuppgifter, bedömning av servicebehovet samt utarbetande och uppdatering av vård- och serviceplaner. Anteckningar är av största vikt inom socialt arbete och vårdarbete, men det är beaktansvärt att man inte försöker begränsa 
den tid som läggs på detta och att det inte alls talas om läsning i till exempel äldreomsorgslagen.

Laura Perttola, som har undersökt äldreomsorgen ur juridisk synvinkel (2019:66), konstaterar vid sin granskning av äldreomsorgslagen (980/2012) att den är ett: "typexempel på att förfaranderättigheter har trätt i de subjektiva rättigheternas ställe: lagen tryggar rätten att söka tjänster, bedöma servicebehovet, utarbeta en serviceplan och fatta beslut utan dröjsmål, men inte själva tjänsterna." (översättning: Semantix Finland)

\section{Texternas inverkan på tillgången till rättigheter och begriplighet}

Textdominansen inverkar även när vi är klient eller patient. Vägen till socialoch hälsovårdstjänsterna går ofta från en text till en annan. Språket som används, texterna som krävs för att uträtta ärenden och som man stöter på när man uträttar ärenden samt kommunikationsmetoderna utgör dock hinder för tillgången till service och de egna rättigheterna. I den socialbarometer som regelbundet genomförs i Finland konstaterades 2016:
Man får inte de nödvändiga socialskyddsförmånerna, eftersom man inte klarar av, kan eller vill ansöka om dem. Utslagningsfaktorer är bl.a. brister i IT- kunskaperna och i skriv, läs-, interaktions- och språkfärdigheterna. [- - - ] Socialskyddsförmåner söks ofta på nätet, vilket gör det svårare att ansöka om stöd för dem som inte har någon dator eller saknar den kompetens som krävs för att använda en dator. Rörelseproblem kan också göra det svårare att ansöka om stöd. För äldre människor är tröskeln för att ansöka om socialskyddsförmåner dessutom ofta hög. (Eronen et. al. 2016:53, översättning: Semantix Finland)

Vad innebär beskrivningen av socialbarometern i praktiken? Ett belysande exempel uppstår när man granskar med vilken process man kan få egenvårdsartiklar som man enligt Finlands lagar (klientavgiftslagen 734/1992; hälsooch sjukvårdslagen 1326/2010) i en viss situation får avgiftsfritt (för en närmare beskrivning av processen se Tiililä 2020:301-303). För att få egenvårdsartiklar måste man först skaffa en remiss av en läkare, alltså besöka en hälsostation. Om man beställer artiklar per telefon ska man sätta sig in i återuppringningssystemet och hur det går till via en meddelandetjänst eller elektroniskt. Om man däremot vill uträtta ärenden elektroniskt, måste man först ingå ett avtal om detta. Avtalet kan i sig ingås elektroniskt eller med en pappersblankett. För att ett avtal ska kunna ingås elektroniskt ska det dock finnas ett kundkonto. För att skapa kontot behövs nätbankskoder eller mobilcertifikat.

Processen inbegriper alltså att man måste skaffa sig olika texter och ta sig till servicekanalerna på besvärliga sätt. En betydande del av t.ex. de äldre har dock aldrig identifierat sig elektroniskt (Ikäihmiset 2017:9; se även Tiililä 2020). I exemplet realiseras Lillis och McKinneys (2013:417) summering att 
skrivandet kommer till uttryck i många former och material och genom många olika typer av teknologi.

Frågor om ansökningsformatet är alltså frågor om språkanvändning och kommunikation: det är fråga om på vilket sätt en person ska kommunicera med myndigheten, och myndigheter har makten att bestämma om det. Att uträtta ärenden skriftligt och elektroniskt är för svårt för många. Juridikprofessor Risto Koulu, som har forskat i överklagande inom socialskyddet, har konstaterat att:

Medborgare i en svag position klarar [-- - ] inte av att strida effektivt för sina rättigheter. De orkar inte, klarar inte av eller kan inte driva sin sak. (Koulu, 2014:24, översättning: Semantix Finland)

Liknande uppgifter om problemen med social- och hälsovårdstjänsterna kommer upprepade gånger fram t.ex. i de årliga socialombudsmännens rapporter från olika kommuner i Finland. Satu Loippo (2019:30) påminner i sin årsrapport om att "för en klient är inte ens de officiella termerna inom socialvården i allmänhet bekanta". Särskilt svårt är det för dem som inte behärskar landets nationalspråk.

Tjänster inom social- och hälsovården används i typfallet i besvärliga, till och med krisartade livssituationer. I en situation av det här slaget skulle många behöva ett lättläst språk, det vill säga en språkform som är ännu enklare än allmänspråket och som i allmänhet riktas till specialgrupper.

Enligt en behovsbedömning behöver 11-14 procent av befolkningen i Finland lättläst språk (Juusola 2019). Antalet har antalet ökat. En bakgrund till detta är att antalet invandrare har ökat. Antalet finländare över 65 år har också ökat, och samtidigt lider allt fler personer av till exempel minnessjukdomar. Ungdomars läsfärdighet i Finland har också försämrats en aning enligt PISA-undersökningen. Dessutom har det konstaterats att vem som helst av oss skulle ha nytta av lättläst språk i en krissituation.

När man talar om kommunikationsrelaterade problem måste man dock utvidga granskningen från problem med förståelsen också till andra problem. Av kunder inom förvaltningen och den offentliga servicen krävs till exempel även förmåga att kategorisera sig själv och kännedom om terminologin. Man måste kunna hitta rätt informationskanal, medium och informationssätt och behärska dem, olika språkgenrer och skrivna och oskrivna lagar i kommunikation (se Maaß 2019:6-8).

Det måste också finnas resurser. Loippo (2019:21) framhäver i socialombudsmannens rapport oron för klienternas ork. Resurserna kan sina när man uträttar ärenden och nödgas till att berätta och skriva. Rapporten innehåller ett direkt citat av responsen från en utmattad förälder. Citat visar att även det skrivande som krävs av dem som använder tjänster kan expandera okontrollerat och kännas som ett oändamålsenligt arrangemang: 
Jag var tvungen att skriva om händelseförloppet, men jag orkar inte. Jag orkar helt enkelt inte längre. Jag har varit tvungen att berätta vår historia tiotals gånger under året. Alltid och varje gång samma historia när en ny instans kommer in $\mathrm{i}$ vårt liv. Skolan, den ständigt växlande barnskyddspersonalen, ungdomspsykiatrin, placeringsinstitutionens personal. Listan är oändlig. Alltid samma historia från början. Jag förstår inte, för det ska väl gå att läsa om oss i journalerna? (Loippo 2019:21, översättning: Semantix Finland)

Med användning av genreforskningens begrepp (Fairclough 1992:71-72) betyder detta att man också måste se medborgaren som en textproducent. Hen har inte bara en roll som mer eller mindre passiv läsare, mottagare eller textkonsument. Det här är ändå en synvinkel som ganska ofta tycks dominera när språket beaktas i utvecklingen av förvaltningen.

I den fallna social- och hälsovårdsreformen i Finland finns exempel också på denna aktiva roll och situation för patienten. Som sagt, är valfrihet en mycket positivt laddad term. I social- och hälsovårdsreformen skulle denna "frihet" dock i praktiken ha inneburit en rätt besvärlig byråkratisk process för medborgarna. I $20 \S$ i utkastet till valfrihetslagen stadgades om hur medborgare borde ha anmält "valet av social- och hälsocentral och mun- och tandvårdsenhet". Den inledande delen av paragrafutkastet lydde så här:

Meddelande om val av social- och hälsocentral samt mun- och tandvårdsenhet.

En kund ska via de informationshanteringstjänster som avses i $77 \S 1$ mom. eller annars skriftligen meddela det landskap där han eller hon är invånare om sitt val av producent av direktvalstjänster, social- och hälsocentral samt mun- och tandvårdsenhet eller lämna meddelandet direkt till den producent av direktvalstjänster som kunden valt. (Regeringens proposition om valfrihetslagen, RP 16/2018:374)

Det skulle alltså ha krävts att man kunde göra en skriftlig anmälan genom att använda en viss, lagstadgad kanal. Anmälan skulle ha föregåtts av en urvalsprocess, som skulle ha krävt att en person klarade av att kartlägga vilka slags alternativ som stod till buds för hen. Att byta ut den valda serviceproducenten skulle också ha krävt en noggrant reglerad byråkratisk ansökningsprocess (slutet av 20 §):

En kund får välja en ny producent av direktvalstjänster, social- och hälsocentral samt mun- och tandvårdsenhet tidigast sex månader från sitt föregående val. [- -] Dessutom kan landskapet på ansökan av kunden ge kunden rätt att oberoende av tidsfristen byta producent av direktvalstjänster, social- och hälsocentral eller mun- och tandvårdsenhet av någon annan grundad anledning. (Regeringens proposition om valfrihetslagen, RP 16/2018:374-375)

Idén om en fri och väljande medborgare var alltså i praktiken en illusion, eftersom den inkluderade en textuell process som skulle ha varit besvärlig för många. Perttola (2019:100-103) konstaterar även att målet med ett aktivt 
medborgarskap - vilket i sig är bra - är besvärligt när en människa är gammal och i dåligt skick, och det är svårt att få information om olika tjänster. Wendel (2019:67/155) kritiserar också situationer där det i och med managerialismen (NPM) krävs att också en patient ska ha rollen som aktiv konsument på ett sätt som kan vara svårt för en orolig, sjuk eller förvirrad person.

I vidare bemärkelse inverkar textualiseringen även på hur begriplig förvaltningen och dess strukturer och verksamhet är. Språkforskaren Pirjo Hiidenmaa (2000:39) har konstaterat att:

För att kunna förstå en text måste man kunna uppfatta dess plats i nätverket av texter. Man måste veta till vilken diskussion ett dokument hör, vilka funktioner som utförs med det, vilka slags funktioner som har utförts med tidigare texter, vad ett enskilt dokument leder till. (Hiidenmaa 2000: 39, översättning: Semantix Finland)

Hiidenmaa talar om textförståelse. När förvaltningen dock bygger på texter och textkedjor är det viktigt att uppfatta nätverket av texter också för att få grepp om förvaltningen. Ett bra exempel på detta är lagstiftning, där man avancerar från olika typer av initiativ till beredning och via lagförslag till lagutkast och fastställda lagar (se Koskela 2008:117; Processhandbok). Att förvaltningen bygger på texter kommer väl till synes också i bild 1 om diagrammen om styrning och rådgivning inom social- och hälsovården (Nykänen et al. 2017:48). Inte undra på att många inte fick grepp om innehållet i reformen.

\section{Rättigheter som bekräftas genom texter}

Jag har nu behandlat relationen mellan språk och rätt ur medborgarnas perspektiv och inom ramen för detta ur två olika infallsvinklar, nämligen rättigheter som kan fås genom texter, det vill säga tillgång till rättigheterna, och texter och uppfattning av förvaltningsstrukturerna. Vi ska ännu titta på en tredje: rättigheter som bekräftas i texter.

Språk, texter och rätt är oskiljaktigt sammanslingrade, eftersom rättigheter uttrycks med hjälp av språket och stadgas i texter. Relationen är ännu djupare när den omständighet som det stadgas om anknyter till kommunikation. Exempel på författningar av det här slaget i Finland är förvaltningslagen, där det i $34 \S$ stadgas om hörande av kunden, och lagen om klientens ställning och rättigheter inom socialvården. Så här står det i lagarna:

Hörande av part

Innan ett ärende avgörs skall en part ges tillfälle att framföra sin åsikt om ärendet och avge sin förklaring med anledning av sådana yrkanden och sådan utredning som kan inverka på hur ärendet kommer att avgöras. (Förvaltningslagen 34 §.)

Självbestämmanderätt och medbestämmande 
När socialvård lämnas skall i första hand klientens önskemål och åsikt beaktas och klientens självbestämmanderätt även i övrigt respekteras. (Lagen om klientens ställning och rättigheter inom socialvården 8 §.)

Även om det är lagstadgat att höra kunden och beakta hens åsikt kan det dock i praktiken hända att de oskrivna lagarna är starkare än de skrivna. Dessa oskrivna lagar finns $\mathrm{i}$ just skrivpraxisen och genrekonventionerna som reglerar vem som hörs och vem som inte hörs och hur detta sker (se Fairclough 1992:78, 80, 102-103). Sirpa Saario (2017), som har forskat i hur dokumenten påverkar vardagen inom arbete med psykisk hälsa, har till exempel konstaterat att:

Det anses att vården av en ny kund kan inledas på riktigt först när handlingarna från den remitterande vårdinstansen (slututlåtandena) erhålls för genomläsning. På så sätt skapar och upprätthåller slututlåtandena ett arbetssätt som i första hand bygger på officiell expertkunskap. Kundens egen muntliga berättelse eller den uppfattning om kundens situation som personalen bildar sig utifrån interaktionen med kunden blir sekundär. (Sirpa Saario 2017:40, översättning: Semantix Finland.)

Liknande forskningsresultat har man fått i forskning om kommunala beslut om handikappservice bl.a. som en del av textkedjan (Tiililä 2007:161-162; 193-194). Besluten fattas utifrån kundens ansökan och olika expertutlåtanden. Även om kunden borde vara den primära informationskällan förekommer hen dock som referenskälla allra minst av de olika informationskällorna. Den informationskälla som nämns oftast är den sökandes egen läkare.

I referenspraxisen genomförde man eller lät bli att genomföra hörandet, så att klienten är lägst $i$ hierarkin av röster och kunskap och den officiella informationen är primär. Kundens egen berättelse eller text om sin situation är sekundär och kunden har alltid lekmannens roll. Också här ser man att det inte räcker med att förstå: man måste kunna producera rätt slags språk för att bli hörd, alltså citerad (Tiililä 2007:160-173, 227-229).

I det här sammanhanget ska jag nu återvända till den kundplan som nämndes i början och som Finlands omsorgsminister år 2017-2019 alltså hade stora förväntningar på. Man förväntar sig mycket av texter och tror på deras kraft, men verkligheten kan dock vara en helt annan när det gäller arbetet och informationssystemen i vardagen. Raija Koskinen (2017), som har forskat i barnskyddsarbete under reformen av informationssystemet, observerade att:

[o]taliga klienter saknade en plan, och en anteckning om att "en klientplan görs upp senare" infördes i klientplanen för många klienter. För systemet räckte det med en död bokstav, form utan innehåll (Koskinen 2017:53, översättning:

Semantix Finland). 
En sådan stor motsägelse mellan förväntningar och praxis kan bero på att man inte känner till eller kan identifiera textarbetets vardag (se även Lillis 2013:96).

\section{Från rättigheter till ojämlikhet och otrygghet}

Jag har ovan presenterat textualiseringens framtoning, bakgrund och konsekvenser särskilt när det gäller att ordna och få social- och hälsovård. Det behövs givetvis texter. Genom dem planeras, dokumenteras, beviljas och förvägras rättigheter. Genom dem uppstår också kontinuitet i arbetet (se Karlsson 2006:101-102). Jag anser dock att det är problematiskt att textarbetet ökar okontrollerat och antagligen delvis oavsiktligt, eftersom man när lagarna stiftas kanske inte alltid identifierar vad som händer i ämbetsverkens vardag, om man till exempel i lagarna om dem föreskrivs om prövning. Det ökade textarbetet grundar sig på ledarskap som syftar till kostnadseffektivitet och till att arbetet går att mäta, men priset på textarbetet och textarbetets verkningsfullhet har dock inte beaktats systematiskt (se även Wendel 2019:14).

I allt större utsträckning löser man med texterna också frågor som inte kan lösas enbart genom textarbete. Det är bra att till exempel skriva in riktlinjerna för arbetarskyddet i arbetarskyddsprogrammet, men problemen löses inte genom att det finns ett dokument. Idéerna ska också implementeras i verksamheten, förankras och övervakas så att de antecknade ärendena förverkligas (Tiililä 2018b).

Ämbetsverken och de offentliga tjänsterna har naturligtvis också konsekvenser för klienterna och patienterna. En direkt följd kan vara att de som arbetar med människor inte längre har tillräckligt med tid att möta klienter och patienter.

Sammanfattningsvis anser jag också att en orsak till olika samhälleliga problem för det första är att språkanvändningen och texterna som anknyter till ärendena blir ett hinder för att få hjälp. Människor hamnar utanför den sociala tryggheten, och mekanismerna som bryter ojämlikheten utlöses inte (Therborn 2014:69-84). När det till exempel är för svårt och arbetskrävande att ansöka om utkomststöd, arbetslöshetsförmåner eller invalidpension, så kan marginaliseringen och instabiliteten i samhället öka.

För det andra är en förvaltning som bygger på textnätverk och det krångliga språk som anknyter till dem svår att uppfatta. Förtroendet för myndigheterna äventyras. Deltagandet i samhällelig verksamhet minskar. Alternativa strukturer, enkla sanningar, populism och ytterlighetsrörelser kan locka.

Och slutligen kör de oskrivna lagarna som hänför sig till textkonventioner och skrivande över de skrivna lagarna, vilket jag visade exempel på genom att presentera konventionerna $\mathrm{i}$ anslutning till hörande av klienten. Texter är förknippade med oavsiktliga och oidentifierade effekter som står i konflikt med de medvetna ambitionerna att utveckla samhället och kan till och med utgöra ett hinder för dem. 
Språk, texter och språkanvändning är på det här sättet kopplade till människors upplevelse av delaktighet. Det sägs att den uppstår när 1) en person har tillräcklig utkomst (having), 2) är aktör i beslutsfattandet om sitt eget liv (acting) och 3) upplever sig höra till i en gemenskap (belonging) (Raivio \& Karjalainen 2013:16).

Alla tre dimensioner är direkt eller indirekt kopplade till språket och språkanvändningen hos myndigheterna, i den offentliga servicen och vid uträttandet av ärenden: Tillgång till tillräckliga materiella resurser kan kräva att man ansöker om förmåner, men som jag har visat i artikeln kan ansökningsprocessen utgöra ett hinder för att få tillgång till förmånen eller tjänsten och därmed en risk för den materiella välfärden. Aktörskapet, inflytandet, valen, beslutsfattandet och självbestämmanderätten stöds i sin tur av att det finns begriplig information om den samhälleliga verksamheten och dess strukturer. Socialt betydelsefulla relationer uppstår i sin tur genom möjligheten att identifiera sig med någon eller något: ur upplevelsen av att den omgivande världen och diskursen även innehåller mig och mina likar (se även Tiililä 2020:307).

$\mathrm{Nu}$ kommer vi från en värld med sociala rättigheter till en annan rättvisans värld. Delaktighetens baksida är marginalisering och en differentiering som leder till ojämlikhet, vilket i Finland har setts som ett säkerhetshot. I Finlands inrikesministeriets framtidsöversikt (Sisäministeriö 2018) konstateras till exempel att:

Fördjupad ojämlikhet och utslagning är betydande bakgrundsfaktorer till traditionella säkerhetshot, t.ex. brottslighet och att bli brottsoffer. Därför måste också de myndigheter som ansvarar för den inre säkerheten ingripa i dem.

(Suomesta turvallinen 2018)

Samma sak kan ses inom kriminalpolitiken, och den finländska kriminalpolitiken sägs bygga på "en nordisk välfärdsmodell, vars principer säger att tryggande av befolkningens välfärd, utbildning och sysselsättning är grundpelaren för ett säkert samhällsliv" (OM 2007:4).

I Finlands nyaste regeringsprogram (Regeringsprogrammet 2019) finns det många åtgärder för att stärka demokratin, delaktigheten och förtroendet för samhällsinstitutionerna: regeringen försöker bekämpa ojämlikhet genom delaktighet.

Innehållet i regeringsprogrammet kan ses som bra och hoppingivande, men man bör vara medveten om att också regeringsprogrammet är en text, vars innehåll inte omvandlas till handling bara sådär. Innehållet i regeringsprogrammet överförs i tjänstemannaberedningen till andra texter, till exempel strategier, och de åtgärdsprogram som följer på dem. Det kan också hända att innehållet inte förs vidare.

Den samhälleliga maktutövningen realiseras i de val som görs i texter och textkedjor. Vid makten finns den som kan påverka de val som görs i texterna, 
och makten förstås av den som känner till metoderna, normerna och processerna för utarbetandet av texterna.

Verksamheten inom förvaltningen och den offentliga servicen är direkt beroende av språket och texterna. Därför anser jag att angreppssätt som bygger på språkvetenskap, såsom skrivandets sociolingvistik eller genreforskning, erbjuder i utvecklingen av förvaltningen och de offentliga tjänsternas möjlighet att granska verksamheten koherent och som en helhet, så att de olika parternas situation och roller beaktas.

\section{Referenser}

Banks, Sarah (2004), Ethics, accountability and the social professions. Consultant editor Jo Campling. Basingstoke: Palgrave Macmillan.

Bhatia, Vijay (1993), Analysing genre. Language use in professional settings. London and New York: Longman.

Blommaert, Jan (2012), Writing as a sociolinguistic object, Tilburg Papers in Culture Studies, No. 42. https://pure.uvt.nl/ws/portalfiles/portal/303579 77/TPCS_42_Blommaert.pdf.

Brown, Gillian \& Yule, George (1983), Discourse analysis. Cambridge: Cambridge University Press.

Eronen, Anne, Lehtinen, Timo, Londén, Pia \& Perälahti, Anne (2016), Sosiaalibarometri 2016, Erityiskatsaus toimeentulosta ja sote-uudistuksesta. Helsinki: SOSTE, Suomen sosiaali ja terveys ry.

Fairclough, Norman (1992), Discourse and social change. Cambridge: Polity Press.

Gunnarsson, Britt-Louise (2009), Professional Discourse. London and New York: Continuum.

Gustafsson, Margareta (2014), "Myndigheternas kunder är vi allihopa?" Språkbruk 4/2014. https://www.sprakbruk.fi/-/myndigheternas-kunder-ar -vi-allihopa-.

Haapamäki, Minna \& Hyry, Johanna (2015), Kirjaamisen kehittyminen sairaanhoitajan työssä. Opinnäytetyö Seinäjoen ammattikorkeakoulu. Seinäjoki University of Applied Sciences. https://www.theseus.fi/bit stream/handle/10024/94500/Haapamaki_Minna.pdf;jsessionid=22F23B0 220E107772E153C0927864E61? sequence=1.

Heikkilä, Elina \& Viertiö, Annastiina (2002), "Keskustelua, kouluttamista ja konsultointia. Kielitoimiston ja Kelan yhteistyö esimerkkinä 2000-luvun kielenhuollosta", i Vesa Heikkinen (red.) Virkapukuinen kieli. Helsinki: SKS, s. 245-258.

Hiidenmaa, Pirjo (2000), "Työ ja kieli", i Vesa Heikkinen, Vesa \& Pirjo Hiidenmaa \& Ulla Tiililä: Teksti työnä, virka kielenä. Helsinki: Gaudeamus, s. 19-34.

Iedema, Rick \& Scheeres, Hermine (2003), "From Doing Work to Talking Work: Renegotiating Knowing, Doing, and Identity", Applied Linguistics 24 (3): 316-337. 
Ikäihmiset 2017, Ikäihmiset ja sähköinen asiointi. Miten saadaan kaikki mukaan? Ikäteknologiakeskuksen raportti 2017. Helsinki: Vanhus- ja lähimmäispalvelun liitto. [https://www.valli.fi/fileadmin/user_upload/Jul kaisutpdf/Raportitpdf/ikaihmisetsahkoinenasiointinetti.pdf].

Johnson, Alison \& Coulthard, Malmcolm (2010), Introduction. Current debates in forensic linguistic", i Malcolm Coulthard \& Alison Johnson (red.), The Routledge Handbook of Forensic Linguistics. London and New York: Routledge, s. 1-15.

Juhila, Kirsi (2009), "Sosiaalityön selontekovelvollisuus", Janus 17 (4): 296-312.

Juusola, Markku (2019), Selkokielen tarvearvio. Selkokeskus, Kehitysvammaliitto ry.

Karlsson, Anna-Malin (2006), En arbetsdag i skriftsamhället. Ett etnografiskt perspektiv på skriftanvändning $i$ vanliga yrken. Småskrift utgiven av Språkrådet. Stockholm: Norstedts Akademiska Förlag.

Karppinen, Kaisa (2019), "Onko asiakas korvannut potilaan terveydenhuollossa?" Kielikello 3/2019. https://www.kielikello.fi/-/onko -asiakaskorvannut-potilaan-terveydenhuollossa-.

Keinänen, Anssi \& Pajuoja, Jussi (2020), Miten vaikutusten arviointia voitaisiin parantaa? Vaikutusarviointi ja sen kehittämistarpeet suomalaisessa lainvalmistelussa. Eduskunnan tarkastusvaliokunnan julkaisu 1/2020. https://www.eduskunta.fi/FI/naineduskuntatoimii/julkaisut/Documents/tr vj_1+2020.pdf.

Koskela, Merja (2008, "Valtionhallinnon tekstilajiketjujen intertekstuaalisia piirteitä”, Käännösteoria, ammattikielet ja monikielisyys. Vaasa: VAKKI:n julkaisut 35, s. 113-126.

Koskinen, Raija (2017), "Lastensuojelun sosiaalityö ja asiakastietojärjestelmä muutoksessa”, i Ulla Tiililä \& Kati Karvinen (red.) Elämän ja kuoleman tekstit. Kirjoittaminen sosiaali- ja hoitotyössä. Helsinki: Kotimaisten kielten keskus.

Koulu, Risto (2014), Sosiaaliturvan muutoksenhakulautakunta lainkäyttäjänä. Helsinki: University of Helsinki Conflict Management Instituten julkaisuja.

Kröger, Teppo, von Aerschot, Lina \& Puthenparambil, Jiby Mathew (2018), Hoivatyö muutoksessa. Suomalainen vanhustyö pohjoismaisessa vertailussa. Jyväskylän yliopisto, YFI julkaisuja - YFI Publications 6.

Lillis, Theresa \& McKinney, Carolyn (2013), "The sociolinguistics of writing in a global context: Objects, lenses, consequences", Journal of Sociolinguistics $17 / 4$, s. $415-439$.

Lillis, Theresa (2019), The Sociolinguistics of Writing. Edinburgh: Edinburgh University Press.

Loippo, Satu (2020), Sosiaaliasiamiehen selvitys vuodelta 2019. Asiakkaiden aseman ja oikeuksien tarkastelua Akaan, Forssan, Hämeenlinnan ja Riihimäen kaupun-geissa sekä Hattulan, Hausjärven, Humppilan, Janakkalan, Jokioisten, Lopen, Tammelan, Urjalan ja Ypäjän kunnissa. 
PIKASSOS OY. Sosiaalialan osaamiskeskus Kanta-Hämeessä, Pirkanmaalla ja Satakunnassa. https://pikassos.fi/aineistot/send/45-osiaaliasia miesaineistot/1265-sosiaaliasiamiehen-vuoden-2019-selvitys.

Maaß, Christiane (2019), Easy Language and beyond: How to maximize the accessibility of communication, Invited Plenary Speech at the Klaara 2019 Conference on Easy-to-Read Language Research, Helsinki, Finland. 1920 september 2019.

Mannermaa, Mika (2004), Heikoista signaaleista vahva tulevaisuus. Helsinki, WSOY.

Manssila, Sonja \& Mattson, Lotta red. (2019). Slutrapport om landskaps- och vårdreformen. Erfarenheter av beredningsarbetet, lärdomar och slutsatser. Finansministeriets publikationer 2019:55. Helsingfors: Finansministeriet.

Myndigheternas skrivregler. Åttonde upplagan. Stockholm: Språkrådet och Norstedts Juridik AB/Fritze 2014.

Mäenpää, Olli (2000), Hallinto-oikeus. Porvoo: Werner Söderström Lakitieto Oy. Mäenpää, Olli (2013), Hallinto-oikeus. Helsinki: Sanomapro Oy.

Nissi, Riikka \& Honkanen, Suvi (2015), 'Kielityön uudet muodot - kielentutkijan katse tieto- ja osaamisyhteiskuntaan". Kieli, koulutus ja yhteiskunta, 9.12.2015 (Joulukuu). https://jyx.jyu.fi/bitstream/handle/123456789/48 077/kielityon-uudet-muodot-kielentutkijan-katse-tieto-ja-osaamisyhteis kuntaan.pdf? sequence $=4 \&$ isAllowed=y.

Nykänen, Eeva \& Kovasin, Merja \& Liukko, Eeva \& Blomqvist, Pia \& Krohn, Minerva \& Ahola, Sanna \& Nurmi-Koikkalainen, Päivi \& Jonsson, Pia Maria (2017), Vaikuttava valvonta osana sosiaali- ja terveydenhuollon uudistusta. Valtioneuvoston selvitys- ja tutkimustoiminnan julkaisusarja 29/2017.

OM 2007, Hyvinvointivaltion kriminaalipolitiikka. Kriminaalipoliittinen toimintaohjelma vuosille 2007-2011. Helsinki: Oikeusministeriö.

Peippo, Malla \& Turunen, Nina (2015), Hoitohenkilökunnan kokemuksia hoitokertomuksen käytöstä Etelä-Savon sairaanhoitopiirissä. Opinnäytetyö MAMK Univesity of Applied Sciences. https://www. theseus.fi/bit stream/handle/10024/97029/Peippo_Malla_Turunen_Nina.pdf?sequence $=1$.

Perttola, Laura (2019), Kynnyksen yli. Julkisoikeudellinen tutkimus vanhuspalvelujen saamisen edellytyksistä. Acta Wasaensis 437. Vaasa: Vaasan yliopisto.

Processhandbok, Processhandbok för lagberedningen. Justitieministeriet, Finlexjulkaisut. http://lainvalmistelu.finlex.fi/sv/tietoa-palvelusta/.

Pyhäniemi, Saija (2017), "Lastenhoitoa vai kirjaamista? Kyselytutkimus kirjaamisesta päiväkodeissa”, i Ulla Tiililä \& Kati Karvinen (red.) Elämän ja kuoleman tekstit. Kirjoittaminen sosiaali- ja hoitotyössä. Helsinki: Kotimaisten kielten keskus, s. 19-30.

Qvist, Anne (2017), "Kuinka toimeentulotukipäätös syntyy Helsingin sosiaali- ja terveysvirastossa?" i Ulla Tiililä \& Kati Karvinen (red.) Elämän ja kuoleman tekstit. Kirjoittaminen sosiaali- ja hoitotyössä. Helsinki: Kotimaisten kielten keskus, s. 103-116. 
Raivio, Helka \& Karjalainen, Jarno (2013), "Osallisuus ei ole keino tai väline, palvelut ovat!", i Taina Era (red.), Osallisuus - oikeutta vai pakkoa? Jyväskylän ammattikorkeakoulun julkaisuja 156.

Rautiainen, Pauli, Taskinen, Helena \& Rissanen, Sari (2020), "Sosiaali- ja terveyspalvelujen uudistaminen- virstanpylväitä menneestä ja suuntia tulevasta", i Anneli Hujala \& Helena Taskinen (red.), Uudistuva sosiaalija terveysala (2020). Tampere: Tampere University Press, s. 15-45. https://trepo.tuni.fi/bitstream/handle/10024/124078/rautiainen_ym_sosia ali_ja_terveyspalvelujen_uudistaminen.pdf? sequence $=2$ \&isAllowed $=y$.

Regeringsprogrammet 2019, Ett inkluderande och kunnigt Finland - ett socialt, ekonomiskt och ekologiskt hållbart samhälle. Regeringsprogrammet för statsminister Sanna Marins regering 10.12.2019. Helsingfors: Statsrådets publikationer 2019:32.

Riksdagen 2008, Revisionsutskottets betänkande 5/2008 rd. Informationsstyrningen inom social- och hälsovården.

Rytkönen, Arja (2018), Hoivatyöntekijöiden työn kuormittavuus ja teknologian käyttö vanhustyössä. Acta Universitatis Tamperensis 2410. Tampere: Tampere University Press. https://repo.tuni.fi/bitstream/handle/10024/ 104482/978-952-03-0829-2.pdf? sequence=1\&isAllowed=y.

Saarikko 2017, Riksdagens plenum torsdag 19.10.2017, muntlig fråga om socialoch hälsovårdsreformen, familje- och omsorgsminister Annika Saarikkos svarsreplik 16:24; översatt från finska.

Saario, Sirpa (2011), "Arviointitekniikat ja mielenterveystyö - tutkimus ammattilaisten luovinnasta työn arvioinnissa ja seurannassa", i Helén Ilpo (red.) Reformin pirstaleet. Mielenterveyspolitiikka hyvinvointivaltion jälkeen. Tampere: Vastapaino, s. 182-230.

Saario, Sirpa (2017), "Asiakirjat mielenterveystyötä ohjaavina välineinä”, i Ulla Tiililä \& Kati Karvinen (red.) Elämän ja kuoleman tekstit. Kirjoittaminen sosiaali-ja hoitotyössä. Helsinki: Kotimaisten kielten keskus.

Sisäministeriö 2018, Suomesta maailman turvallisin maa. Sisäministeriön tulevaisuuskatsaus. Valtioneuvoston julkaisusarja 18/2018. Helsinki: Sisäministeriö.

Stensöta, Helena (2010), "The Conditions of Care: Reframing the Debate about Public Sector Ethics". Public Administration Review 70:2, s. 291-324.

Suomesta turvallinen 2018: Sisäministeriön turvallisuuskatsaus: Suomesta yhtä turvallinen kaikille. Pressmeddelande på internet om framtidsöversikten 4.6.2018.

Swales, John (1990), Genre Analysis. English in academic and research settings. Cambridge, New York, Port Chester, Melbourne, Sydney: Cambridge University Press.

Therborn, Göran (2014), Eriarvoisuus tappaa. Tampere: Vastapaino.

Tiililä, Ulla (2000), "Tapaus päivähoitopäätös”, i Vesa Heikkinen, Pirjo Hiidenmaa \& Ulla Tiililä. Teksti työnä, virka kielenä. Helsinki: Gaudeamus, s. 214-266.

Tiililä, Ulla (2001), "Näkymiä tekstityöhön ja työteksteihin". Kielikello 3/2001, s. 7-11. 
Tiililä, Ulla (2007), Tekstit viraston työssä. Tutkimus etuuspäätösten kielestä ja konteksteista. Helsinki: SKS.

Tiililä, Ulla (2011), ’Sanoilla lavastettu virasto. Tietoyhteiskunnan arkea sosiaalija hoiva-aloilla", i Marjut Johansson, Pirkko Nuolijärvi \& Riitta Pyykkö (red.) Kieli työssä. Asiantuntijatyön kielelliset käytännöt. Helsinki: SKS, s. $162-189$.

Tiililä, Ulla (2015), Makt genom myndighetsspråk. Myt och verklighet, i Jorunn Simonsen Thingnes (red.) Fra myndig maktspråk til klar kommunikasjon. Rapport fra Nordisk klarspråkskonferanse Oslo, 28.-29. mai 2015. Nätverket för språknämnderna i Norden, s. 99-106.

Tiililä, Ulla (2017), "Sosiaali- ja terveyspolitiikkaa kielen ja kielikäsitysten varassa", i Sirkku Latomaa, Emilia Luukka \& Niina Lilja (red.) Kielitietoisuus eriarvoistuvassa yhteiskunnassa - Language awareness in an increasingly unequal society, s. 54-71. https://journal.fi/afinlavk/ issue/ view/4674.

Tiililä, Ulla (2018a), "Legal Discourse As An Example Of Domain-Specific Science Communication", i John Humbley, Gerhard Budin \& Christer Laurén (red.) Languages for Special Purposes. An International Handbook. Berlin, Boston: De Gruyter Mouton, s. 381-405.

Tiililä, Ulla (2018b), Päästäänkö häirinnästä eroon työsuojelohjelmalla? Valtiolla.fi-julkaisuja. https://valtiolla.fi/paastaanko-hairinnasta-eroontyosuojeluohjelmalla/.

Tiililä, Ulla (2020), Asiointikielen rooli vanhuspalvelujen saavutettavuudessa, i Kaarina Hippi, Anne Mäntynen \& Camilla Lindholm (red.) Vanhuus ja kielenkäyttö. Helsinki: SKS, s. 288-315.

Vehko, Tuulikki, Pekkarinen, Laura, Lämsä, Riikka, Aalto, Anna-Mari, Virta, Lauri, Kokko, Simo, Keskimäki, Ilmo \& Elovainio, Marko (2015), Lääkäreiden ajankäyttö, työolot ja lausunnut perusterveydenhuollossa. Työpaperi 31/2015. Terveyden ja hyvinvoinnin laitos. https://www. julkari.fi/bitstream/handle/10024/129501/URN_ISBN_978-952-302567-7.pdf? sequence=1\&isAllowed=y.

Wendel, Lotta (2019), Dokumentation, profession och hälso- och sjukvård. Rättsliga perspektiv. Malmö University, Health and Society, Doctoral Dissertation 2019:3.

\section{Lagstiftning}

Förvaltningslag 6.6.2003/434.

Hälso- och sjukvårdslag 30.12.2010/1326.

Lag om klientavgifter inom social- och hälsovården 3.8.1992/734 terveydenhuoltolaki.

Lagen om klientens ställning och rättigheter inom socialvården 22.9.2000/812.

Lag om ändring av lagen om stödjande av den äldre befolkningens funktionsförmåga och om social- och hälsovårdstjänster för äldre 9.7.2020/565.

$\mathrm{RP} 15 / 2017 \mathrm{rd}=$ Regeringens proposition till riksdagen med förslag till lagstiftning om inrättande av landskap och om en reform av ordnandet av social- och hälsovården samt till lämnande av underrättelse enligt artikel 12 och 13 i Europeiska stadgan om lokal självstyrelse. 
RP 16/2018 rd = Regeringens proposition till riksdagen med förslag till lag om kundens valfrihet inom social- och hälsovården och till vissa lagar som har samband med den RP 16/2018. 